\title{
The Role of Export and Terms of Trade for an Economy with Resource Dependence, Case of Algeria
}

\author{
Mohammed Touitou ${ }^{1}$, Tahar Djellit ${ }^{2}$, Ahmed Boudeghdegh ${ }^{3}$
}

\begin{abstract}
The paper analyses the impact of foreign trade to GDP growth in Algeria on the basis of cointegration analysis. The aim of the paper is to assess causal relations between exports, oil prices, terms of trade and economic growth. The literature discusses different options: a positive unidirectional relation from exports growth and terms of trade improvement to economic growth (export-led growth), opposite relation from economic growth to export growth and bidirectional causal relations between indicators, negative effects of exports are also discussing. In this paper we firstly provide a statistical overview of the dynamics of foreign trade over the last decade and calculate terms of trade index. Secondly, we conduct an econometric analysis of the interdependence of indicators: GDP growth, exports, terms of trade and the price of oil in terms of vector error correction model (VECM). We consider two model specifications for quarterly and annual data, perform "Granger causality" test for the time series data. We found positive short-term and longterm dependence of economic growth on export and oil prices and long-term dependence on the terms of trade, bidirectional relations was not identified. The results confirm the high dependence of the economy on the external sector and export-led growth hypothesis. Thus, exports and foreign trade should be considered as a source of economic growth for the country, the external sector is important to consider when building the economic growth forecast and modeling of economic policy.
\end{abstract}

Keywords: Economic growth; Algeria, VECM, Foreign trade.

\section{Introduction}

The choice of foreign policy that leads to economic growth is questionable and thus popular among economists. The contribution of the external sector to growth is controversial: on the one hand, most developing countries pursue a strategy of economic growth based on exports; on the other hand, economists note that focusing on foreign trade can have a negative impact on domestic production.

Proponents of export-led growth have noted that this policy leads to economic specialization and obtaining economies of scale (Helpman, Krugman, 1985), besides the export sector should be effective to compete in foreign markets, it helps to create a market for highly skilled workers, to develop and disseminate technology, to borrow innovative technology abroad (Grossman, Helpman, 1991). Thus the theory of international trade suggests that export growth has a positive effect on economic growth (export-led growth). It is also important to note that economists consider the opposite effect - the effect of the production growth on exports (Krugman, 1984, Ghartley, 1993; Dutt, Ghosh, 1996). The authors note that GDP growth presupposes growth

${ }^{1}$ Senior Lecturer in Applied Economics and Statistics. University of Algiers 3"Faculty of Economics and Managements" - Algeria

2Senior Lecturer in Economics. University of Jijel"Faculty of Economics and Managements" - Algeria

"Senior Lecturer in Economics. University of Jijel"Faculty of Economics and Managements" - Algeria 
performance and cost savings, making exports more effective.

Among the theories that consider negative role of foreign trade, there is a theory of the "resource curse" or the Dutch disease. The theory suggests that the permanent export of resources leads to depletion of recourse stocks in the leading sector, and exchange rate appreciation causes a decrease in the effectiveness of other types of exports. Thus there is a negative impact of export on the production (Sachs, Warner, 2001).

With considerable energy resources, Algeria is a leader in Africa in production and export of energy that defines the strong dependence of the economy on the external sector. The volume and price of exports, as well as the terms of trade have traditionally been used by the authors for the analysis of the Algerian economy. The nature of the impact of exports on economic growth seems ambiguous: export revenues form the state budget, but the negative effects on the domestic market is also highlighted by the authors, there are no a large number of studies that analyze the Dutch disease in Algeria. Thus, the assessment of the nature and direction of the impact of the external sector to the economic growth in Algeria is relevant issue.

There are different approaches to econometric estimation of the effect of trade on economic growth, including cross-country studies, which are based on an assessment of the cross-sectional correlation and regression of cross-sectional data (Balssa, 1978, Feder, 1982), another group of researchers works with time series (Ghartley, 1993 , Dutt, Gosh, 1996). The disadvantage of the first approach is that it does not take into account the specific characteristics of the countries. Using time series avoids this problem. Among the difficulties of working with time series are: the selection of lag length, the choice of method for determining causality, sensitivity to model specification (Hatemi-J, Irandoust, 2000). In this paper we analyze the mutual influence of the external sector on economic growth and vice versa using time series. In particular, we use the vector error correction model (VECM), which is based on the use of cointegration relationships between the variables, the question of the length of the lag and the definition of Granger causality will be resolved in the framework of this model.

The work consists of an introduction, two parts and conclusions. The first part is the statistical analysis of the export sector in the Algerian economy, we analyze the main trends; in the second part we conduct an econometric analysis of the relationship of GDP growth, exports, terms of trade and export prices. Discussion of the results of the study are presented in the conclusion.

\section{Statistical Analysis of the Current Conditions of Algerian Foreign Trade}

Today, after eight years from the start of the global crisis, the global economy can not fully return to the path of profitable and sustainable growth. Moreover, current crisis processed in developing countries contribute to the growth of global imbalances. It affects the country's economy strongly if the country is actively involved in international trade in goods and services and dependent on foreign capital.

Here we consider the overall picture of foreign trade of Algeria for 2005-2015. Data clearly shows two periods of development (Figure 1). Before the crisis, data presents a positive trend in terms of foreign trade; the year 2009 is associated with a sharp decline in exports; the period 2010-2012 can be called the gradual recovery of the Algerian economy. 


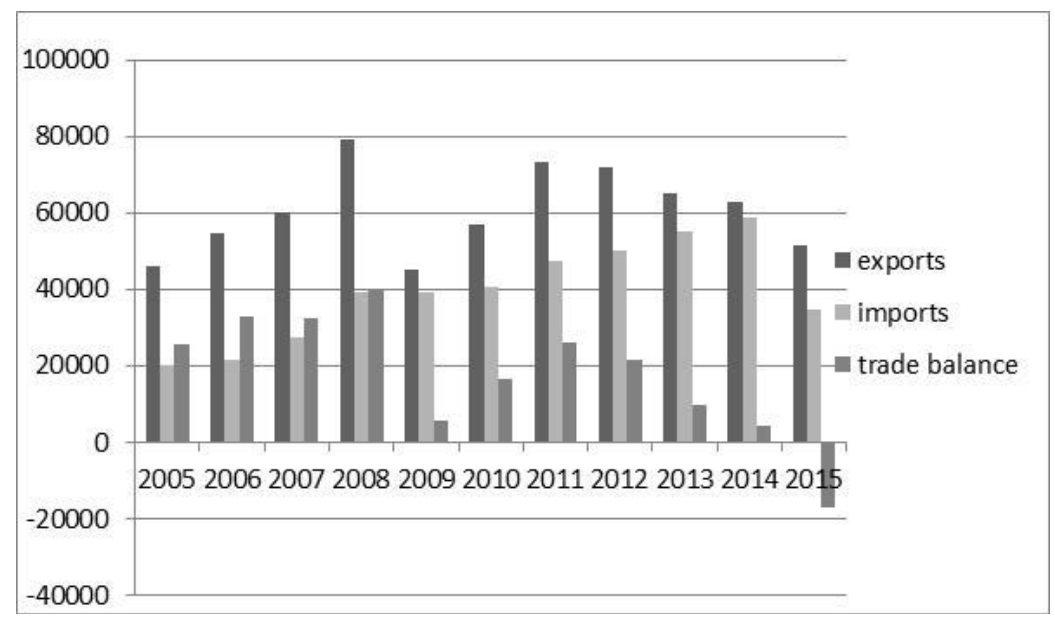

Figure 1. Indicators of Algera's foreign trade in goods (bln. USD)

Source: National Center for Informatics and Statistics, Algerian customs.

The basis of Algerian exports over the last decade mainly consists of fuel and energy products, thus prices for fuel and energy products, particularly oil have significant impact on the dynamics of balance of payments.

Algeria's oil industry plays a significant role in the development of the domestic economy. Algeria has some of the largest deposits of oil and natural gas across the globe. With such an abundance of hydrocarbons, the country is among the top producers worldwide. It's hardly surprising then, that the main industry is the extraction and processing of oil and gas products. These make up more than 95\% of Algeria's export revenues and contribute to two-thirds of the country's spending budget. Algeria's estimated 12 billion barrels of oil reserves and tenth-largest reserves of natural gas are of particular interest to foreign oil companies, who have been allowed to invest in Algeria since the 1990s.

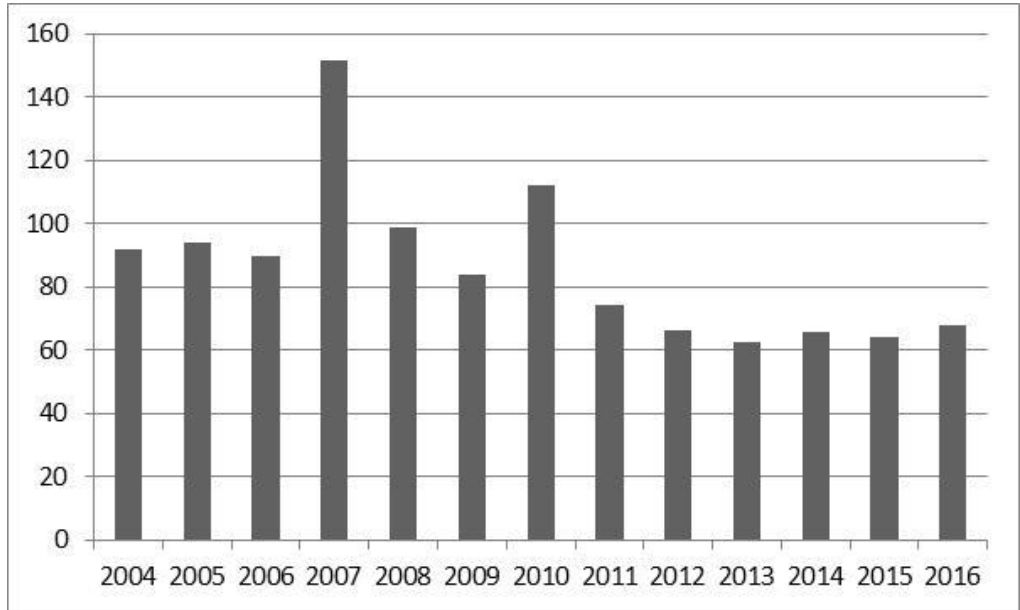

Figure 2. Dynamics of Algerian crude oil exports for 2004-2016. (mln. tons). Source: 
National Center for Informatics and Statistics, Algerian customs Largely decrease in exports is due to the increased supply of petroleum resources to domestic refineries: in 2013, these supply increased by 3\%. However, the reduction in demand from international partners is a priority factor. Demand, in turn, is related to the dynamics of commodity prices and the level of production growth in the economies. The change in export prices is influenced by many factors such as the number of explored and involved in the trafficking field, the emergence of new technologies and changes in the cost of oil, which leads to daily fluctuations (Figure 3).

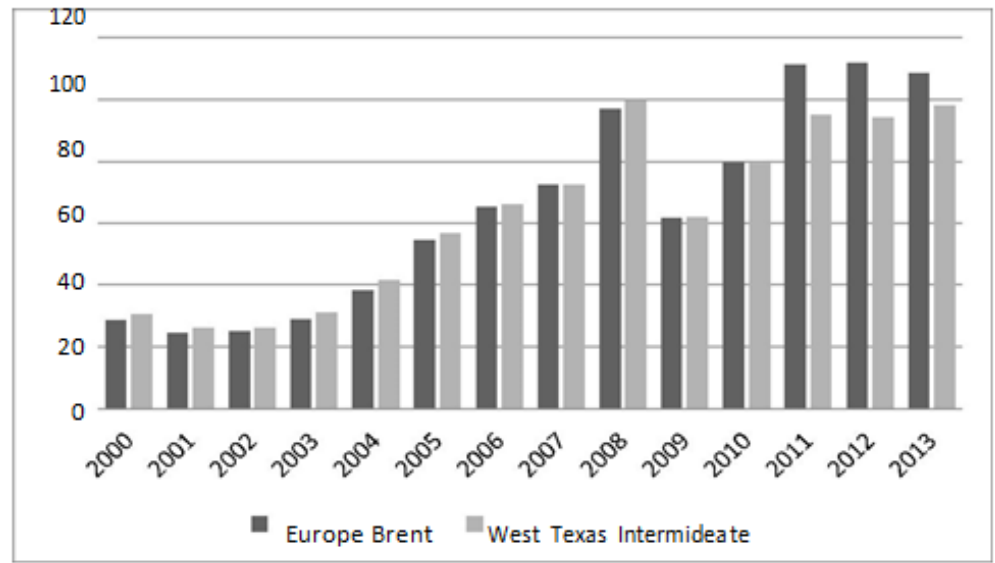

Figure 3: Average annual oil price of WTI US and European Brent crude USD per barrel Source: Thomson Reuters, ELA

Except the export prices is important to consider the ratio of export and import prices for the analysis of the trade balance of the country. The terms of trade (TT) is calculated as the ratio

of the cost of a basket of major export commodities to the value of a basket of major import commodities.

\section{$T T=\underline{\operatorname{Index}(E X)}$}

\section{Index(IM)}

The calculation of this indicator is made using the data of Rosstat of the average import and export prices for basic goods. Product baskets were calculated as:

$$
\operatorname{Index}(E X)=\frac{\sum_{j=1}^{m} \sum_{i=1}^{n} Q_{j}^{j} \cdot P_{i}}{\sum_{j=1}^{m} \sum_{i=1}^{n} Q_{j}^{j} \cdot P_{0}},
$$

where $Q j$ - the amount of good $j$ in total exports in the base year, $P_{i}$ - the price of goods at the moment i. A similar calculation is made for the imported goods.

Dynamics of terms of trade in the Algerian economy is presented in Figure 4. 


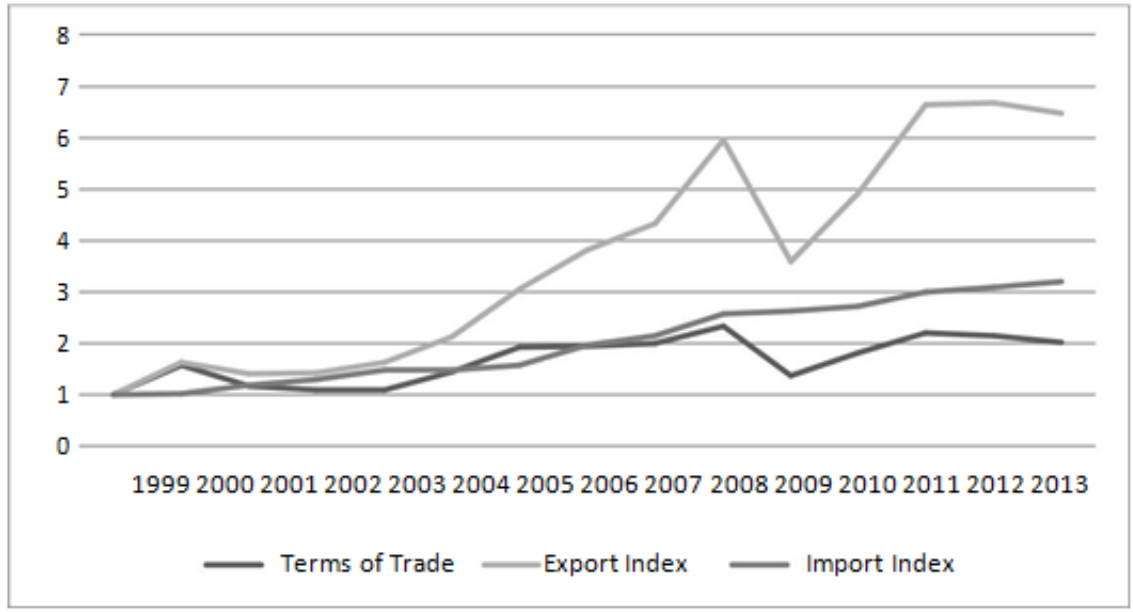

Figure 4. Dynamics of terms of trade (units)

Source: National Office of Statistics, authors calculations

In terms of trade dynamics we also observe the effect of the global financial crisis: a sharp decline in the index in 2009. By 2013, the pre-crisis level of the indicator was not achieved.

At the same time the pace of economic growth (Figure 5) partly repeats the dynamics of oil prices and terms of trade dynamics. This is not surprising, as the share of exports in GDP has changed over the period under review from 44\% in 2000 to almost 30\% in 2012 (according to the National Economic and Social Council).

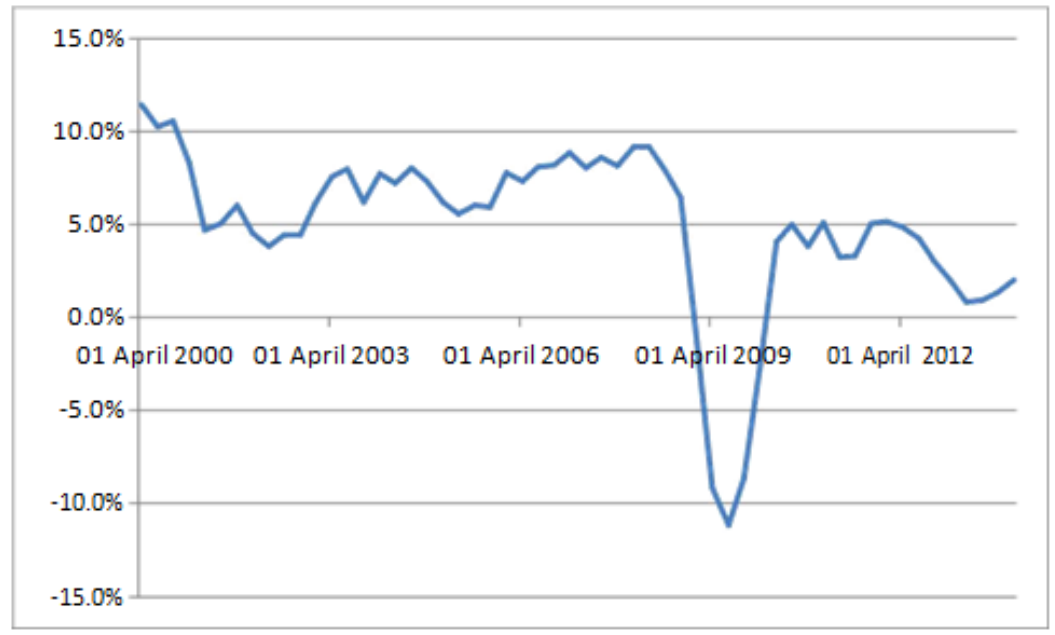

Figure 5. Dynamics of GDP growth (base year), \% to the same period of the previous year.

Source: National Office of Statistics, authors calculations

To summarize foreign trade is of great importance for the Algerian economy. Thus, the earnings volatility in this sector is a serious problem for the economy. In the next part of 
the paper we will consider what contribution the dynamics of exports and the price of oil makes to GDP growth. The aim of the practical part of the study will be the analysis and testing of short-and long-term dependence of energy prices, exports, terms of trade and GDP growth.

\section{An Analysis of the Interdependence of Trade Performance and Economic Growth}

As noted earlier estimation of the hypothesis of the dependence of the external sector and growth in the economy is quite common in the literature. Impact of exports of goods, particularly in resource-dependent countries can shoe itself in different ways. Papers based on the analysis of Granger causality, allow us to estimate the direction of the relationship between the indicators and the degree of their influence. Granger test is to test the causal link ("Granger causality") between the time series. The Granger causality test is a statistical hypothesis test for determining whether one time series is useful in forecasting another.

On the basis of this test the papers for the United States has shown that economic growth leads to the export growth (Ghartley, 1993; Dutt, Ghosh, 1996), although a weak reverse effect was also found in the paper of Zestosa and Tao (2002). The interdependence of exports and GDP growth is shown for Canada (Zestos, Tao, 2002), Japan (Ghartley, 1993). Studies for developing countries show mixed results: for South Asian countries (Indonesia, Malaysia, Philippines, Singapore) the hypothesis of causality from GDP to exports is supported, ie, the traditional approach, which explains the growth of Asian economies through the expansion of exports has not been confirmed (Ahmad, Hrnhirun, 1996). Test results for Argentina and Mexico showed a

one-directional dependence of exports and GDP growth, for Brazil authors show causality from exports to GDP (Maneschiold, 2008), for Turkey there is a one-way causality from GDP to exports (Akbay, 2011). In addition to the value of exports authors usually include to the model specification import (Zestos, Tao, 2002; Akbay, 2011), the terms of trade, prices of the main traded goods, the index of industrial production (Awokuse, 2004). We should note that we did not find papers with these methods of empirical research to test Algerian data. That explains the choice of methodology for this study and makes it relevant.

The test is conducted within the framework of the vector model correction regression residuals (VECM), which is adjusted for the error model of vector autoregression (VAR). Taking into consideration models discussed above we include the following variables to the model: real GDP growth, export, index for oil price, the terms of trade.

Variables:

\begin{tabular}{|l|c|}
\hline Gross domestic product & GDP \\
\hline Export & EX \\
\hline Oil price index & Indoil \\
\hline Terms of trade & TT \\
\hline
\end{tabular}

For all variables, except the last, we use quarterly data for the period 2004-2015. Due to 
the fact that the information on the prices of export products is in annualized format while the other variables have quarterly data, we decided to evaluate the two regression models:

1) The model on quarterly data

$\Delta \log G D P+\Delta \log E X+\Delta$ Indoil + Const $+\varepsilon$

2) The model on the annual data

$\Delta \log G D P+\Delta T T+$ Const $+\varepsilon$

We will estimate by the following hypotheses:

- Positive long-term relationship between GDP growth and other variables (EX, Indoil, TT);

- Long-term effects of variables (EX, Indoil, TT) to the GDP growth rate;

- Long-term impact of GDP growth on the other indicators (EX, Indoil, TT);

- Short-term dependence of the variables GDP (EX, Indoil, TT);

- The short-term impact of growth rate of GDP on the other indicators (EX, Indoil, TT).

\subsection{Testing of the model for quarterly data}

VECM model implies working with data - non-stationary in levels and stationary in first differences. To verify the data we use Dickey-Fuller unit root test. The test results are shown in Table 1.

Table 1: Dickey-Fuller Unit Root Test

HO: The time series are non-stationary, have a unit root $* *$. 5\% significance level here and further.

\begin{tabular}{|l|c|c|l|l|}
\hline \multicolumn{1}{|c|}{ Variables } & ADF Test Statistics & T stat. & Prob. & \multicolumn{1}{|c|}{ Results } \\
\hline LGDP & -3.115123 & -3.568379 & 0.1211 & $\begin{array}{l}\text { Non- } \\
\text { stationary }\end{array}$ \\
\hline LEX & -2.513786 & -3.557759 & 0.3198 & $\begin{array}{l}\text { Non- } \\
\text { stationary }\end{array}$ \\
\hline LIndoil & -2.400288 & -3.568379 & 0.3720 & $\begin{array}{l}\text { Non- } \\
\text { stationary }\end{array}$ \\
\hline dLGDP & $-3.49784^{* *}$ & -2.954021 & 0.0144 & Stationary \\
\hline dLEX & $-4.10788^{* *}$ & -2.954021 & 0.0031 & Stationary \\
\hline dLIndoil & $-3.4273^{* *}$ & -2.967767 & 0.0181 & Stationary \\
\hline
\end{tabular}

H0: The time series are non-stationary, have a unit

root **. $5 \%$ significance level here and further.

Variables are in line with our assumptions, the hypothesis of no unit root in first differences is not rejected.

The number of lags is determined by the Akaike's Information Criterion and Likelihood Ratio Test, the optimal number of lags in the model is one. We also test for the presence of cointegration between the variables. Building a VAR model is only possible if the variables are cointegrated. 
Table 2: Johansen cointegration test

\begin{tabular}{|c|c|c|c|c|c|}
\hline $\begin{array}{c}\text { Hypothesized } \\
\text { No. of CE(s) }\end{array}$ & Eigenvalue & $\lambda$ trace & $\begin{array}{c}0.05 \text { Critical } \\
\text { Value }\end{array}$ & $\lambda$ max & 0.05 Critical Value \\
\hline $\mathrm{r}=0$ & & 75.011 & 29.797 & 48.444 & 21.131 \\
\hline $\mathrm{r} \leq 1$ & 0.4802 & 26.566 & 15.494 & 24.209 & 14.264 \\
\hline $\mathrm{r} \leq 2$ & 0.0617 & $2.356^{* *}$ & 3.841 & $2.356^{* *}$ & 3.841 \\
\hline
\end{tabular}

Methodology Johansen is a generalization of the Dickey-Fuller test. The method is using two criteria likelihood, $\lambda$ trace and $\lambda \max$, to determine the nu mber of cointegration vectors (r). In accordance with the results of Table 2 , there are two cointegrating vectors. However, we test only one of them, because the second vector does not include the influence of the volume of export to other variables.

So, we get cointegration vector VEC1 $(\theta t)$, which takes into account all the variables under consideration (t-statistics is in brackets):

$\operatorname{VEC}_{1}\left(\theta_{\mathrm{t}-1}\right): 1 *$ LGDP $-0.297638 * \mathrm{LEX}+0.239907 *$ LIndoil - 5.517476

\section{$[-17.7183] \quad[1.67172]$}

The results show that the variable export is characterized by a negative sign in the cointegration vector, which puts it in direct long-term dependence on GDP. Factor price index for oil has a positive sign; the coefficients are almost identical in size. Both variables significant at the $10 \%$ significance level. The coefficient on export significant at the $5 \%$ level of significance, and the coefficient of the price index is not.

On the basis of the cointegration relationship obtained we construct vector error correction model. It is a system of equations for each endogenous variable, ie, a system of three equations. On the left side of the equation there are the logarithm of each of the first differences of variables, on the right - lagged values of the differences of all variables and lagged cointegration vector $\theta \mathrm{t}-1$, which is a deviation of the system from a long-term relation (VEC1 $(\theta \mathrm{t}))$.

$\Delta L G D P_{t}=\alpha_{1}+\alpha_{L G D P} \theta_{t-1}+1 i \Delta L G D P_{t-1}+1 i \Delta L E X_{t-1}+1 i \Delta L I N D O I L_{t-1}+\varepsilon_{1 t}$ $\Delta L E X_{t}=\beta_{2}+\beta_{L G D P} \theta_{t-1}+2 i \Delta L G D P_{t-1}+2 i \Delta L E X_{t-1}+2 i \Delta L I N D O I L_{t-1}+\varepsilon_{2 t}$ $\Delta L I D O I L_{t}=\gamma_{3}+\gamma_{L G D P} \theta_{t-1}+3 i \Delta L G D P_{t-1}+3 i \Delta L E X_{t-1}+3 i \Delta L I N D O I L_{t-1}+\varepsilon_{3 t}$ (3) Indicators $\alpha \mathrm{ti}, \beta \mathrm{ti}, \gamma \mathrm{ti}$ are coefficients of the endogenous variables, which are estimated in the model, $\varepsilon$ - shocks in the equations (1) - (3). The estimation results are shown in Table 3.

Table 3: The estimation results for equations (1) - (3)

\begin{tabular}{|c|l|l|l|l|}
\hline \multicolumn{5}{|l|}{$\Delta$ LGDP: } \\
\hline & Coefficient & Std. Error & t-Statistic & Prob. \\
\hline$\alpha \theta_{\mathrm{k}: 1}$ & -1.281113 & 0.230141 & -5.566650 & 0.0000 \\
\hline$\alpha_{\mathrm{li}}$ & 0.696767 & 0.169624 & 4.107718 & 0.0003 \\
\hline$\beta_{1 \mathrm{i}}$ & -0.270285 & 0.095168 & -2.840085 & 0.0078 \\
\hline$\gamma_{1 \mathrm{i}}$ & 0.869548 & 0.141667 & 6.137979 & 0.0000 \\
\hline$\alpha_{\mathrm{l}}$ & 0.012153 & 0.009827 & 1.236693 & 0.2252 \\
\hline
\end{tabular}




\begin{tabular}{|c|c|c|c|c|}
\hline \multicolumn{5}{|l|}{$\triangle \mathrm{LEX}:$} \\
\hline$\beta \theta_{n-1}$ & 0.216167 & 0.427206 & 0.506001 & 0.6163 \\
\hline$\alpha_{2 i}$ & -0.192413 & 0.314869 & -0.611089 & 0.5455 \\
\hline$\beta_{2 \mathrm{i}}$ & 0.165747 & 0.176659 & 0.938232 & 0.3552 \\
\hline$\gamma_{2 \mathrm{i}}$ & 1.332387 & 0.262973 & 5.066621 & 0.0000 \\
\hline$\beta 2$ & 0.025874 & 0.018242 & 1.418372 & 0.1657 \\
\hline \multicolumn{5}{|c|}{$\triangle$ LINDOIL: } \\
\hline$\gamma \theta_{\mathrm{t}-1}$ & 0.021823 & 0.281445 & 0.077539 & 0.9387 \\
\hline$\alpha_{3 \mathrm{i}}$ & -0.254474 & 0.207438 & -1.226747 & 0.2289 \\
\hline$\beta_{3 i}$ & -0.038200 & 0.116384 & -0.328222 & 0.7449 \\
\hline$\gamma_{3 i}$ & -0.237065 & 0.173248 & -1.368353 & 0.1807 \\
\hline$\gamma$ & 0.005623 & 0.012018 & 0.467858 & 0.6431 \\
\hline
\end{tabular}

We can draw the following conclusions:

- There is a long-term dependency of GDP growth from other variables, vector tends to the long-term equilibrium;

- GDP growth does not affect other variables;

- There is a short-term GDP dependence on exports;

- There is a short-term GDP dependence on the price index;

- There is a short-term export dependence on oil prices;

- Oil price index is not affected by the amount of export and GDP growth.

Thus at this stage of the analysis on quarterly data we conclude that data confirms the short-term and long-term effects of exports to the growth of GDP, as we expected. The reverse causality from GDP to exports is not revealed. Oil price index does not depend on other variables that can be explained by the fact that prices should not be predictable.

\subsection{Testing of the model for annual data}

For the analysis of the second model we take annual data on GDP growth and terms of trade. The objective of this model is to analyze the impact of the variable characterizing the conditions of trade in Algeria (TT) (Fig. 5).

To avoid the problem of lack in data for econometric analysis we take a longer evaluation period from 1999 to 2015. We then perform the same algorithm as earlier. Firstly, we conduct tests for a unit root and prove that data is suitable for analysis. Secondly, the number of lags in the model is defined by Akaike criterion. The optimal number of lags is 2 . In accordance with the Johansen test model has at least one cointegration relationship, its estimation is shown below.

VEC2 ( $\theta \mathrm{t}-1): 1 *$ LGDP - $0.41812 *$ TT -.748756 [-9.47585]

According to the results, the rate of GDP growth is positively related to the terms of trade. Terms of trade ratio are significant at the $1 \%$ level of significance.

VEC model is a system of 2 equations at first differences.

$\Delta L G D P_{t}=\alpha_{1}+\alpha_{L G D P} \theta_{t-1}+1 i \Delta L G D P_{t-I}+1 i T T_{t-I}+\varepsilon_{1 t}$

$T T_{t}=\beta_{2}+\beta_{T T} \theta_{t-1}+2 i \Delta L G D P_{t-I}+2 i T T_{t-I}+\varepsilon_{2 t}$

Estimation results are presented in table 4 . 
Table 4: The estimation results for equations (4) - (5)

\begin{tabular}{|c|c|c|c|c|}
\hline \multicolumn{5}{|l|}{$\triangle \mathrm{LGDP}$} \\
\hline & Coefficient & Std. Error & $\mathrm{t}$-Statistic & Prob. \\
\hline$\alpha \theta_{\mathrm{t}-1}$ & 0.195126 & 0.352139 & 0.554115 & 0.5995 \\
\hline$\alpha \theta_{t-2}$ & 0.860848 & 0.648214 & 1.328029 & 0.2325 \\
\hline$\alpha_{\mathrm{ii}}$ & -0.381269 & 0.622036 & -0.612937 & 0.5624 \\
\hline$\beta_{1 i}$ & -0.045034 & 0.076562 & -0.588211 & 0.5778 \\
\hline$\beta_{2 i}$ & 0.037614 & 0.060867 & 0.617964 & 0.5593 \\
\hline$\alpha$ & 0.020998 & 0.040286 & 0.521208 & 0.6209 \\
\hline \multicolumn{5}{|l|}{ TT } \\
\hline$\beta \theta_{t-1}$ & 4.760145 & 2.474136 & 1.923962 & 0.1027 \\
\hline$\beta \theta_{t-2}$ & 6.489927 & 4.554364 & 1.424991 & 0.2040 \\
\hline$\alpha_{\mathrm{ii}}$ & -1.576082 & 4.370436 & -0.360624 & 0.7307 \\
\hline$\beta_{1 i}$ & 0.055150 & 0.537923 & 0.102525 & 0.9217 \\
\hline$\beta_{2 i}$ & 0.320802 & 0.427652 & 0.750146 & 0.4815 \\
\hline$\beta_{1}$ & -0.180547 & 0.283052 & -0.637856 & 0.5471 \\
\hline
\end{tabular}

The estimation results that there is no short-term and long-term relationships between the variables at $5 \%$ level of significance. So, the direct impact of the terms of trade on GDP data and vice versa is not observed.

These results can be explained by the fact that for the second regression we used annual data, and the impact of the terms of trade to GDP growth can be observed only within the year. Unfortunately, the official data on the prices of export and import goods is not presented by the National Office of Statistics. Given that causality from export and oil priced to GDP was found with a lag of one quarter, one can assume that the annual data is not enough for identifying causal relationship of GDP growth and terms of trade.

\section{Conclusion}

Discussions about the prospects for the domestic economy and methods of economic growth have always been a great interest among the public, the media and scientific literature. Algeria has large reserves of natural resources, the main engine of trade and economic development is the resource sector.

In this paper we aimed to estimate the contribution of exports, oil prices and the terms of trade to economic growth. The degree and direction of the contribution of the external sector to growth is estimated on the basis of time series data in the vector error correction model. Analysis of the literature shows that in a number of developed and developing countries, there is causality from GDP to exports, which suggests a primary role of productivity growth in the country. Reverse causality from exports to GDP growth corresponds to the idea of export-led growth.

Estimation of the relationship between the factors was made in two models: the quarterly and annual model. Estimation on quarterly data has revealed a positive shortterm and long-term dependence of GDP growth on exports which corresponds to the idea of export-led growth. So, export fluctuations had decisive importance for GDP 
growth for the last decade. The role of exports in the development of the Algerian economy can hardly be overestimated. Dependency of GDP growth from oil prices is also confirmed. The direct impact of the terms of trade on GDP data is not found in our view, it is primarily associated with using annual data for analysis.

Causality from GDP to other variables has not been identified, ie, hypothesis of primary role of productivity and domestic demand is not confirmed. On the contrary, the data shows the decisive role of foreign trade in country's economic growth that characterizes the Algerian as the export-oriented economy. Thus, it is important to take into account the external sector of the economy, when building the economic growth projections and modeling of economic policy in Algeria.

\section{References}

Ahmad J.H. Cointegration and causality between exports and economic growth: Evidence from the ASEAN countries / Canadian Journal of Economics. 1996. 29:S413-6.

Akbay O. S. Trade-Growth Nexus: Turkish Case // Euro Economica. 2011. Issue 2(28).

Awokuse T.O. Is the export-led growth hypothesis valid for Canada? // Canadian Journal of Economics. 2003. Vol. 36, No. 1 February.

Balassa, B. Exports and economic growth: further evidence // Journal of Development Economics. 1978. №5, 181-9.

Dutt, S. D. and Ghosh D. The Export Growth-Economic Growth Nexus: A Causality Analysis // Journal of Developing Areas. 1996. 30, 167-182.

Feder, G. Exports and Economic Growth / Journal of Development Economics. 1982. 12, pp. 59-73

Ghartey, E. Causal Relationship between Exports and Economic Growth: Some Empirical Evidence in Taiwan, Japan and the US // Applied Economics. 1993. 25, 1145-1152.

Grossman, G.M., Helpman E. Innovation and Growth in the Global Economy / Cambridge, MA: MIT Press, 1991.

Hatemi-J A., Irandoust M. Time-series evidence for Balassa's export-led growth hypothesis // J. Int. Trade \& Economic Development. 2000. 9:3 355-365.

Helpman, E., Krugman P. Market Structure and Foreign Trade / Cambridge, MA: MIT Press, 1985.

Maneschiold P. A note on the Export-led growth hypothesis: A time series approach // Cuadernos de Economía. 2008. vol. 45, pp. 293-302.

Polbin A.V. Development of a Dynamic Stochastic General Equilibrium Model for an Economy with High Dependence on Oil Export // HSE Economic Journal. 2013. № 2.

Sachs J.D., Warner A.M. Natural Resources and Economic Development: The Curse of Natural Resources // European Economic Review. 2001. 45 (May): 827-38.

Sosunov K., Zamulin O. Monetary Policy in an Economy Sick with Dutch Disease // CEFIR/NES Working Paper No. 101, 2007.

Zestos G.K., Tao X. Trade and GDP Growth: Causal Relations in the United States and Canada // Southern Economic Journal. 2002. Vol. 68, No. 4, 859-874 